Article

\title{
Sedimentary Landscape of Mun Valley Prehistoric Site: Construction History of Moated Site of Ban Non Wat, Northeast Thailand
}

\author{
Nelum Kanthilatha ${ }^{1, *(\mathbb{C}, \text { William Boyd }}{ }^{2}$ (I) and Nigel Chang ${ }^{3}$ \\ 1 Department of Anthropology, University of Sri Jayewardenepura, Nugegoda 10250, Sri Lanka \\ 2 School of Environment, Science and Engineering, Southern Cross University, East Lismore, NSW 2480, \\ Australia; william.boyd@scu.edu.au \\ 3 College of Arts, Society and Education, James Cook University, Townsville, QLD 4810, Australia; \\ nigel.chang@jcu.edu.au \\ * Correspondence: nelumyapa@sjp.ac.lk
}

Academic Editors: Dolores R. Piperno and Valentí Rull

Received: 22 October 2019; Accepted: 16 January 2020; Published: 20 January 2020

\begin{abstract}
This research examines the sedimentological evidence of human occupation on different cultural layers at the prehistoric archaeological sites in northeast Thailand. This study focuses on the sedimentological characters of stratigraphic layers identified at the prehistoric occupation sites of Ban Non Wat and Nong Hua Raet, to demonstrate the capacity of such analyses to elucidate the modification of sediments by past anthropogenic activity, and eventually to contribute to an enhanced understanding of the behaviour of ancient people. The primary intention of this paper is, therefore, to point out potential uses of particle analysis in identifying human-landscape interventions, testing whether meaningful differentiation is possible, and if not, whether this may nevertheless be used to understand the sedimentological relationships between different features. The study finds that although there is relatively little differentiation between sediments across the archaeological site, some insight is possible in identifying relationships between the natural sediments of the floodplain, the channels associated with the archaeological sites, and the archaeological sediments themselves. It is, for example, now possible to raise new questions regarding the construction history of the sites, the history of human behaviour at these sites, socio-spatial relationships between paleo-social activity and natural resources, and fine-scale landscape associations between sites.
\end{abstract}

Keywords: northeast Thailand; prehistoric settlement; sedimentology; anthropogenic sediments; Mastersizer

\section{Introduction}

\subsection{Sediment History of the Site}

This study describes the first detailed sedimentological analysis of the cultural layers of prehistoric occupation at two sites in northeast Thailand. The sedimentary challenge posed at such a site is that most, if not all, of the archaeological sediments are derived from the same geological prominence-that is, the surrounding floodplain. Differentiating the sediments of the archaeological stratigraphy is critical in terms of interpreting the archaeological history of the site. Grain size analysis provides a potentially valuable approach of understanding the process of transportation of channel sediments from the surrounding floodplain to the site, and their subsequent reworking by the prehistoric occupants of the sites. The close similarities between the sediment characteristics of what are understood to be hard floors and the channel sediments closely associated with the sites would suggest, for example, the plastering of hard floors by using channel clays [1]. Such results are consistent with the results of fatty acids, multi-elements, phytolith and diatom analyses of the site [1,2]. Analysis of this nature has great 
potential to provide a rich evidence of connection to the daily social life of man throughout a long period of prehistory in this region.

This study, therefore, provides an example of how particle analysis can be an interpretive technique. It highlights how this approach might help to identify anthropogenic influence within a sedimentary record, especially in a typical archaeological situation where there is a reasonably uniform background particle distribution; that is, where the bulk of archaeological sediments, regardless of their feature of deposition, have the same geological prominence. The primary intention of this paper is, therefore, to point out the potential uses of particle analysis in identifying human-landscape interventions.

\subsection{Particle Size Analysis}

Particle size is a fundamental property of sediments which demonstrates much about their origins and history, and the size distribution is also an essential property of sedimentary particles. The grain size of the sediments provides a sensitive indicator of the sedimentary environment. Grain-size parameters have been employed to characterize and recognize various depositional processes and environments $[3,4]$. The major features of the alluvial environment are channels and flood-basins. Channel segments may be braided or meandering and carry coarser sand- and gravel-grade detritus in bed-forms confined within the channel banks. Flood basins receive silt- and mud-laden waters during periods of flooding greater than bank-full discharges. The shape of sedimentary particles is a complex property, such that there are even differences of opinion as to what constitutes shape. The size of the component particles is one of the fundamental textural characteristics of all fragmentary deposits and their lithified equivalents. Grain size depends on the character of the source rocks, weathering processes, abrasion, and selective sorting during transportation [4-8].

The relative proportions of grain sizes within a sediment reflect its source and history, and therefore are important to analysis and understanding in any sedimentological analysis. The record of grain size distributions is presented in terms of normal sediment grain size distributions, and the direction and degree to which that distribution deviates from the norm; the deviation from the norm contains information regarding source and history. The deviation is recorded as skewness and kurtosis $[7,8]$. Color is an important attribute in the description of many sedimentary rocks and now highly using a standard color chart that published by the Geological Society of America based on the Munsell Color System [9].

\subsection{Laser Diffraction Analysis}

Laser diffraction analysis has been widely used as a method for particle size distribution analysis of sediments over the past 15 years [10]. Modern computer processing of grain size data facilitates the rapid computation of moment mean grain size, standard deviation, skewness and other statistical properties. These properties of grain size distributions are fundamental descriptive parameters and they find wide usage in sedimentological studies. Laser diffraction analysis is a cost-effective method of undertaking particle size analyses of sands and sand-mud mixtures. The technique has excellent precision and provides a rapid and reliable means of sample comparison [10].

The grain size distribution analysis presented in this paper provides a detailed characterization of the sediments from different cultural layers of occupations, prehistoric buried channel sediments and the compacted hard floor sediments at the two archaeological sites at northeast Thailand. The goal of this research is to study the grain-size distribution of sediments belonging to the different prehistoric occupations across the mound of Ban Non Wat, and compare the mound sediments along with buried channel sediments at the same site. The Nong Hua Raet mound site was selected for the comparison of the Ban Non Wat sediments with the nearby site of occupation.

\subsection{Existing Knowledge of the Study Area}

Boyd and McGrath opened trenches in the same archaeological site with a mechanical digger radially outwards from the mound's edge at nearby sites including Ban Non Wat [11]. The analysis 
of the sections revealed that the banks were constructed from sediments removed from the ground surface; the space between these banks was flat and in due course infilled with sediments brought in by the stream or river that fed into them. Radiometric dating indicates that bank construction and the active infilling of the sediments within the moats occurred during the later Iron Age occupation [12]. Importantly, the archaeological sites are closely associated with these channels, which, in places, can be found under, and in-filled by, subsequent archaeological sediments; they can be shown to have been present at the time of the site's occupation and later overtopped by expanding occupation material [13].

It is now well understood that the prehistoric settlement of Northeast Thailand was intimately associated with use and management of fluvial resources [14]. Prehistoric society in this region relied on fluvial water supplies, and developed much of its social functioning around water reliability and control; society and environment evolved in tandem, each influencing the other, and thus forming a self-reinforcing system of change. While this has been considered to be a feature largely unique to later prehistory (the Iron Age), it is now recognized that water management, from early relatively benign harvesting, through low-impact landscape modification, to later extensive hydro-engineering, has been a distinctive characteristic of the prehistoric occupation of this now-dry region [14,15]. Importantly, Boyd and Chang (2010) have argued that this long-term landscape-scale evolving relationship between society and the management of natural resources has been a central component of understanding socio-cultural development in the region [14]. Excavation at nine localities at Ban Non Wat has identified a number of channel features, at least one of which is now known to have been active in early prehistoric period of occupation.

These previous studies have largely focused on the macro (landscape) scale, and demonstrate that the archaeological sites largely represent continued recycling and reuse of local floodplain sediments. This is the source of the archaeological challenge: how to differentiate the sediments excavated archaeologically to yield evidence of past human behavior, especially where that behavior, sedimentologically, is intimately associated with a limited geological source of material. The present study, therefore, focuses the detailed sedimentological analysis of the buried channel sediments and associated occupation layers of the Ban Non Wat-to test whether meaningful differentiation is possible, and if not, whether this may nevertheless be used to understand the sedimentological relationships between different features.

\section{Methods}

\subsection{Sample Selection and Analysis}

The prehistoric excavation sites of Ban Non Wat and Nong Hua Raet, in Northeast Thailand were selected for the sample collection (Figure 1). Ban Non Wat is a moated site about $300 \mathrm{~m}$ in diameter, rising up from the surrounding floodplain (Latitude $15016^{\prime} 16.73^{\prime \prime} \mathrm{N}$ and Longitude $102016^{\prime} 4.81^{\prime \prime} \mathrm{E}$ ). Samples were selected from the five excavation pits (named as P300, S400, G104, N96, and U200) across the mound of Ban Non Wat (Figure 2), and from one sequence from Non Hua Raet (HI100), representing different cultural layers of occupation (Table 1). Overall, the site comprises layers of archaeological materials, made up of undifferentiated sediments and some identifiable features (burials and post holes, for example, which are not sampled here), through which a number of river or stream channels were cut. Some of these contained alluvial infill sediments. The site was excavated in $10 \mathrm{~cm}$ spits, largely through the undifferentiated archaeological sediments. Where sediments were recovered from these spits, they are labelled 'General spit'. Amongst these were a few distinctive sedimentary features, the most notable being labelled 'Hard floor', a notable layer of compacted sediments, excavated as a feature [16]. Several river channels were identified cutting through the archaeological sediments, and samples were collected immediately below the cut, within it, either as channel fill or archaeological material above it but within the cut of the channel, or above the cut. 


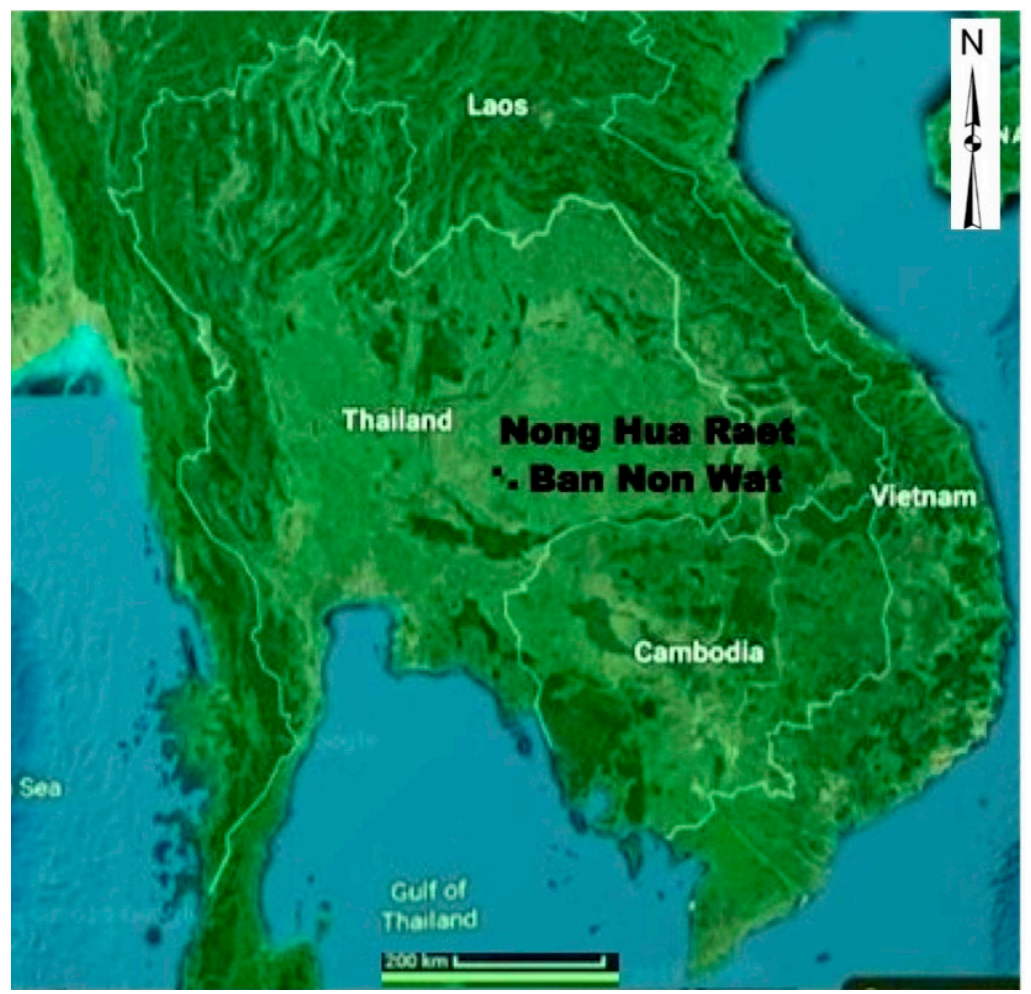

Figure 1. Study sites of Ban Non Wat and Nong Hua Raet at Nakhon Ratchasima province, Non Sung District, Northeast Thailand (Google Earth Image, 2019).

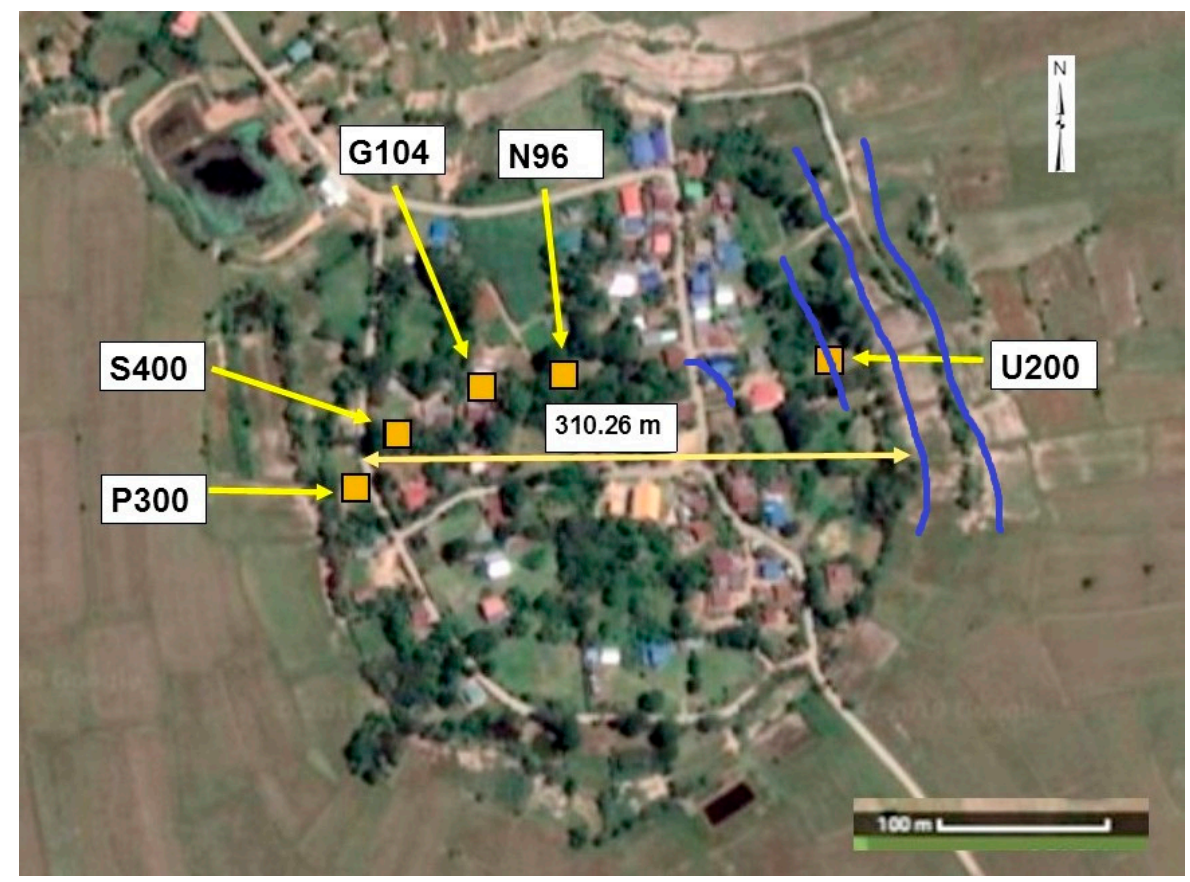

Figure 2. Google map view of the moated settlement of Ban Non Wat and distribution of excavation pits across the moated settlement. Studied samples are from the excavation squares of P300, S400, G104, N96, and U200. Blue lines in right side of the image indicate the channel features.

The excavation pit of U200 represents the buried channel (Figure 2) and samples were taken from each $15 \mathrm{~cm}$ distance from top to bottom, including above to the channel (AB), channel filling $(\mathrm{CF})$, within the channel: channel floor (WC) and below to the channel (BC) (Figure 3). The excavation pit of 
N96 represents the middle area of the mound (Figure 4). Samples from the nearby site of Nong Hua Raet were selected for the comparison purpose of a neighboring site (Figure 5). One compacted hard clay floor sample was selected in each site with other general spit sediments (Table 1). The procedures used to determine the range of particle sizes present in bulk sediments are commonly referred to as particle size distribution analyses $[10,17]$. The particle size analysis of the samples was conducted using Malvern Mastersizer 2000 at the Southern Cross Geoscience laboratory (see supplementary material). Untreated sediment samples were first lightly crushed with a pestle and mortar to remove aggregates.

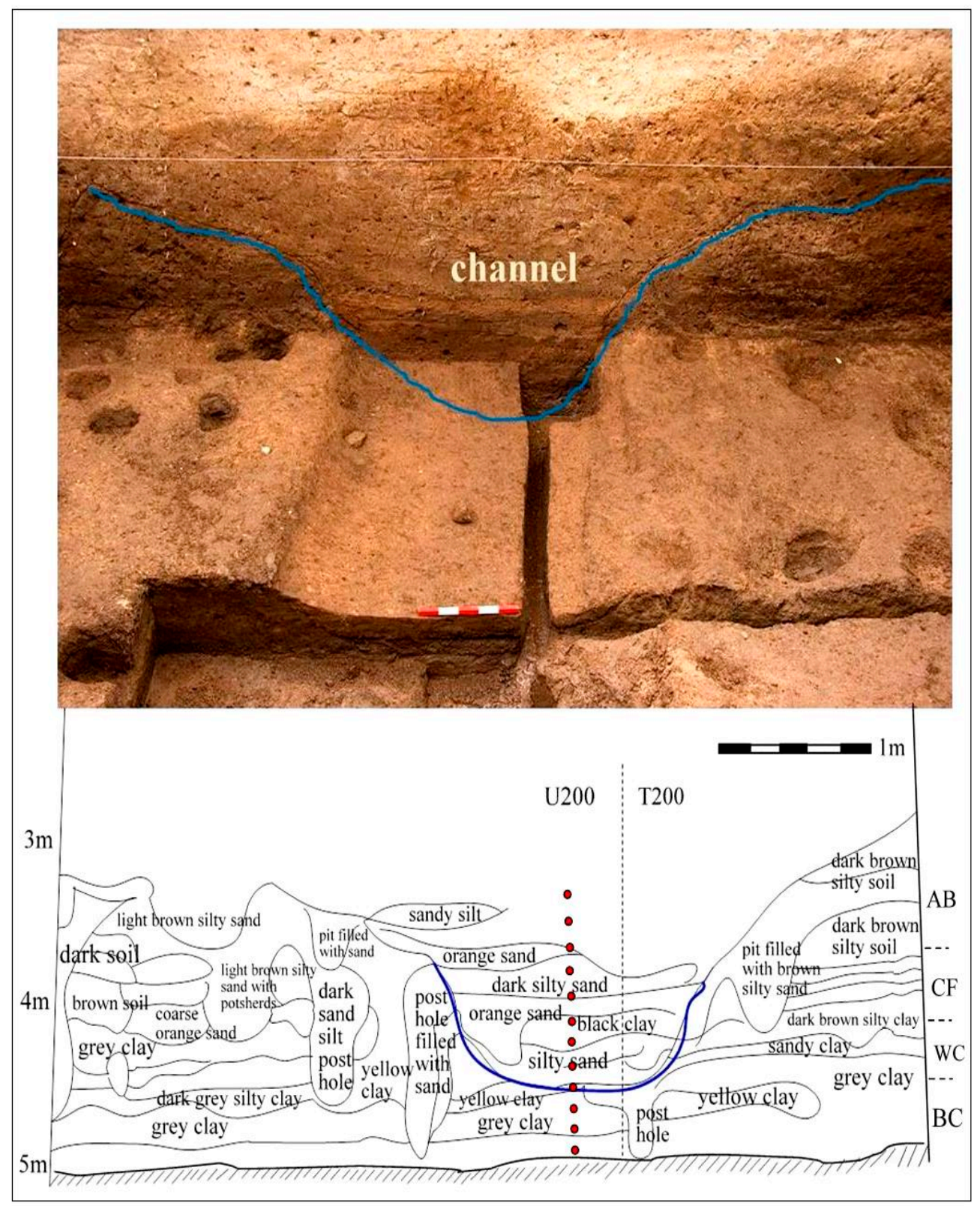

Figure 3. Sampling context across the U200 channel. Photograph shows the U200 excavation across the channel feature. Section plan indicates the channel standing with surrounding stratigraphy (Red dots show the sampling contexts of above channel (AB), channel fill (CF), within channel (WC) and below to the channel (BC) sediments), (photograph: Nigel Chang, line diagram: Nelum Kanthilatha). 
Table 1. Details of the general characteristic of the studied sediment samples. Color identification is based on the Munsell color chart. Period of occupation is based on the macroscopic characteristics identified in the excavations on unpublished excavation reports and available radiocarbon dating $[13,16,18]$.

\begin{tabular}{|c|c|c|c|c|}
\hline Excavation Pit & $\begin{array}{c}\text { Archaeological Layer: Spit } \\
\text { Number, Place }\end{array}$ & Color & Textural Group & Period of Occupation \\
\hline P300 & 3:1 General Spit & 10YR 5/2 & Coarse Silt & Iron Age \\
\hline P300 & 3:5 General Spit & 7.5YR 4/2 & Very Fine Sand & Iron Age \\
\hline P300 & 5:2 Hard Floor (HF) & $7.5 \mathrm{YR} 3 / 2$ & Very Coarse Silt & Iron Age \\
\hline P300 & 5:2 General Spit & $7.5 Y R 3 / 3$ & Very Coarse Silt & Iron Age \\
\hline P300 & 6:5 General Spit & $10 \mathrm{YR} 4 / 3$ & Fine Sand & Bronze Age \\
\hline P300 & 7:2 General Spit & $10 Y R 3 / 2$ & Very Fine Sand & Bronze Age \\
\hline S400 & 1:6 General Spit & 10YR 5/1 & Very Coarse Silt & Recent \\
\hline S400 & 2:3 General Spit & 10YR 5/2 & Coarse Silt & Iron Age \\
\hline S400 & 2:6 General Spit & $10 Y R 5 / 2$ & Coarse Silt & Iron Age \\
\hline $\mathrm{S} 400$ & 2:11 General Spit & $10 Y R 4 / 3$ & Very Coarse Silt & Iron Age \\
\hline $\mathrm{S} 400$ & 3:2 Hard Floor & $10 Y R 5 / 3$ & Coarse Silt & Iron Age \\
\hline $\mathrm{S} 400$ & 3:3 General Spit & $10 Y R 5 / 2$ & Very Coarse Silt & Iron Age \\
\hline S400 & $6: 1$ General Spit & $10 Y R 4 / 2$ & Coarse Silt & Bronze Age \\
\hline G104 & 1:4 General Spit & $10 Y R 5 / 3$ & Very Coarse Silt & Iron Age \\
\hline G104 & 2:5 General Spit & $10 Y R 5 / 2$ & Very Coarse Silt & Iron Age \\
\hline G104 & 3:3 General Spit & $10 Y R 3 / 2$ & Very Coarse Silt & Iron Age \\
\hline G104 & 4:5 General Spit & 10YR 2/1 & Coarse Silt & Bronze Age \\
\hline G104 & 5:1 General Spit & 2.5YR 3/1 & Very Coarse Silt & Neolithic \\
\hline G104 & 6:1 Hard Floor & $10 Y R 5 / 3$ & Coarse Silt & Neolithic \\
\hline G104 & 7:2 General Spit & 7.5YR 2.5/1 & Very Coarse Silt & Neolithic \\
\hline G104 & 7:4 General Spit & 10YR 5/3 & Very Coarse Silt & Neolithic \\
\hline N96 & 1:6 General Spit & 10YR 5/1 & Very Coarse Silt & Iron Age \\
\hline N96 & 2:2 General Spit & $10 Y R 5 / 2$ & Very Fine Sand & Iron Age \\
\hline N96 & 3:3 General Spit & $10 Y R$ 5/1 & Very Coarse Silt & Iron Age \\
\hline N96 & 4:4 Hard Floor & $10 \mathrm{YR} 3 / 1$ & Coarse Silt & Iron Age \\
\hline N96 & 4:5 General Spit & $7.5 \mathrm{YR} 3 / 2$ & Very Coarse Silt & Iron Age \\
\hline N96 & 5:4 General Spit & $10 \mathrm{YR} 5 / 1$ & Coarse Silt & Bronze Age \\
\hline N96 & 6:6 General Spit & 10YR 5/1 & Very Fine Sand & Bronze Age \\
\hline N96 & 6:13 General Spit & 10YR 3/1 & Very Coarse Silt & Bronze Age \\
\hline U200 & Below Channel (BC) & 10YR 4/1 & Coarse Silt & Neolithic \\
\hline U200 & Below Channel & $5 Y 4 / 1$ & Very Coarse Silt & Neolithic \\
\hline U200 & Below Channel & $10 \mathrm{YR} 4 / 2$ & Medium Silt & Neolithic \\
\hline U200 & Within Channel (WC) & 10YR 3/1 & Very Coarse Silt & Neolithic \\
\hline U200 & Within Channel & 2.5YR 3/1 & Coarse Silt & Neolithic \\
\hline U200 & Within Channel & $10 Y R 3 / 2$ & Very Coarse Silt & Neolithic \\
\hline U200 & Within Channel & $10 \mathrm{YR} 2 / 2$ & Very Coarse Silt & Bronze Age \\
\hline U200 & Channel Filling (CF) & $10 Y R 3 / 3$ & Very Coarse Silt & Bronze Age \\
\hline U200 & Chanel Filling & $10 \mathrm{YR} 3 / 3$ & Very Coarse Silt & Bronze Age \\
\hline U200 & Chanel Filling & $10 \mathrm{YR} 4 / 3$ & Very Coarse Silt & Iron Age \\
\hline U200 & Chanel Filling & $10 Y R 4 / 4$ & Very Coarse Silt & Iron Age \\
\hline U200 & Above Chanel (AC) & $10 Y R 5 / 3$ & Very Coarse Silt & Iron Age \\
\hline U200 & Above Chanel & $10 Y R 5 / 2$ & Very Coarse Silt & Iron Age \\
\hline HI100 & 1:7 General Spit & $10 Y R 6 / 2$ & Very Fine Sand & Historic \\
\hline HI100 & 2:4 General Spit & $10 Y R 6 / 3$ & Very Fine Sand & Iron Age \\
\hline HI100 & 3:9 General Spit & $10 \mathrm{YR} 2 / 2$ & Very Coarse Silt & Iron Age \\
\hline HI100 & 3:10 General Spit & $10 \mathrm{YR} 3 / 2$ & Very Fine Sand & Iron Age \\
\hline HI100 & 3:10 Hard Floor & $10 \mathrm{YR} 2 / 2$ & Very Coarse Silt & Iron Age \\
\hline HI100 & 4:1 General Spit & 10YR 6/4 & Very Fine Sand & Iron Age \\
\hline
\end{tabular}




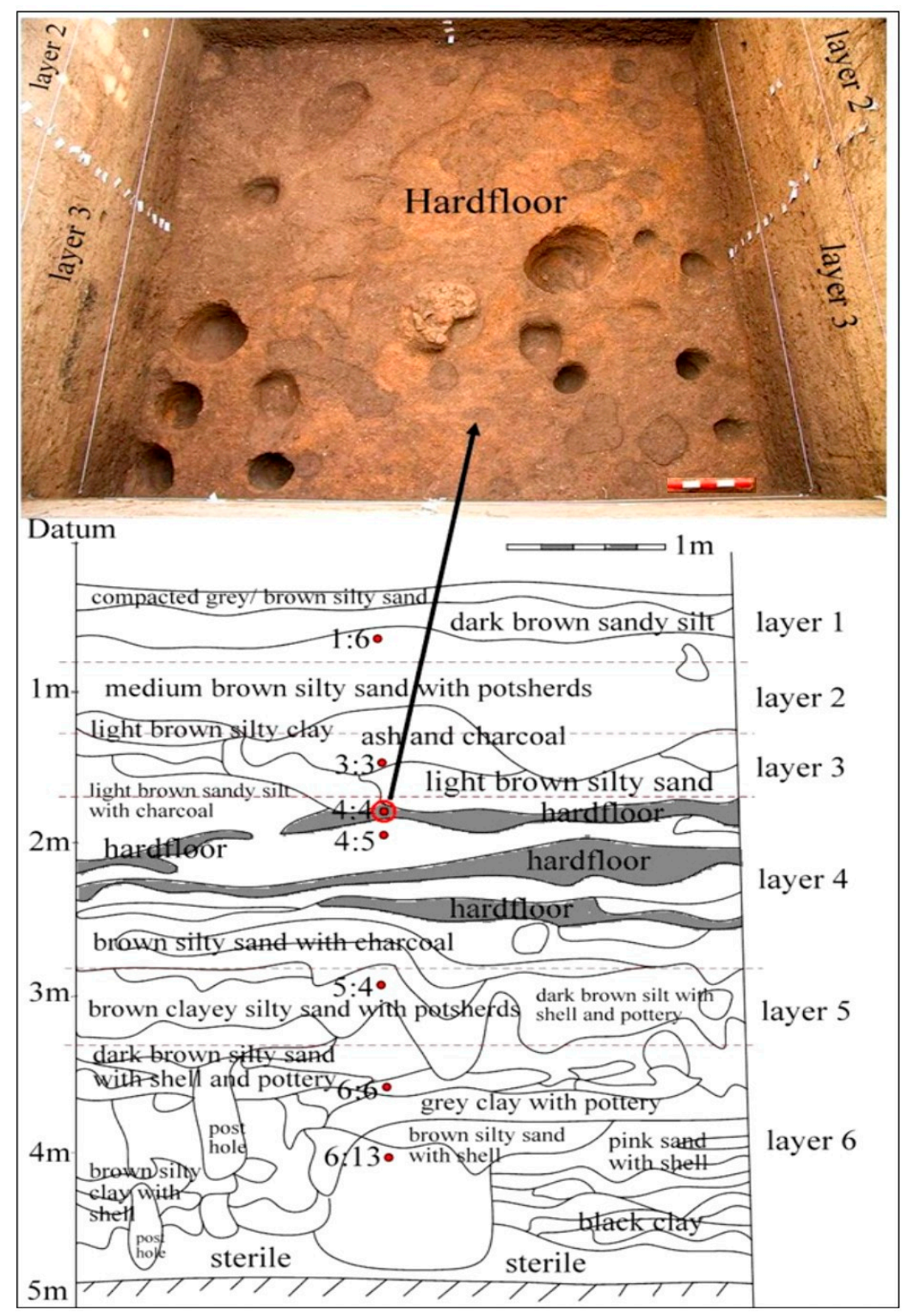

Figure 4. Stratigraphy of N96 sampling context (red dots indicate the sampling context; layer number: spit number). (Photograph: Nigel Chang; Line diagram: Nelum Kanthilatha).

Particle size distributions were measured using a Malvern Mastersizer 2000 laser diffraction particle size analyzer with Hydro 2000 software, which has a detection range from 0.01 to 10,000 $\mu \mathrm{m}$. About a quarter teaspoon of sodium polymetaphosphate and ultrasound were applied to the samples for $20 \mathrm{~s}$ in order to break up any remaining aggregate particles. Three measurements were taken from each sample to check the reliability of the measurements. The mean of each set of results was reported in further calculations. Output of the Hydro 2000 software determined the percentage by volume of sand $(62.5-10,000 \mu \mathrm{m})$, silt $(2-62.5 \mu \mathrm{m})$ and clay $(0.01-2 \mu \mathrm{m})$ particles of each sample. 


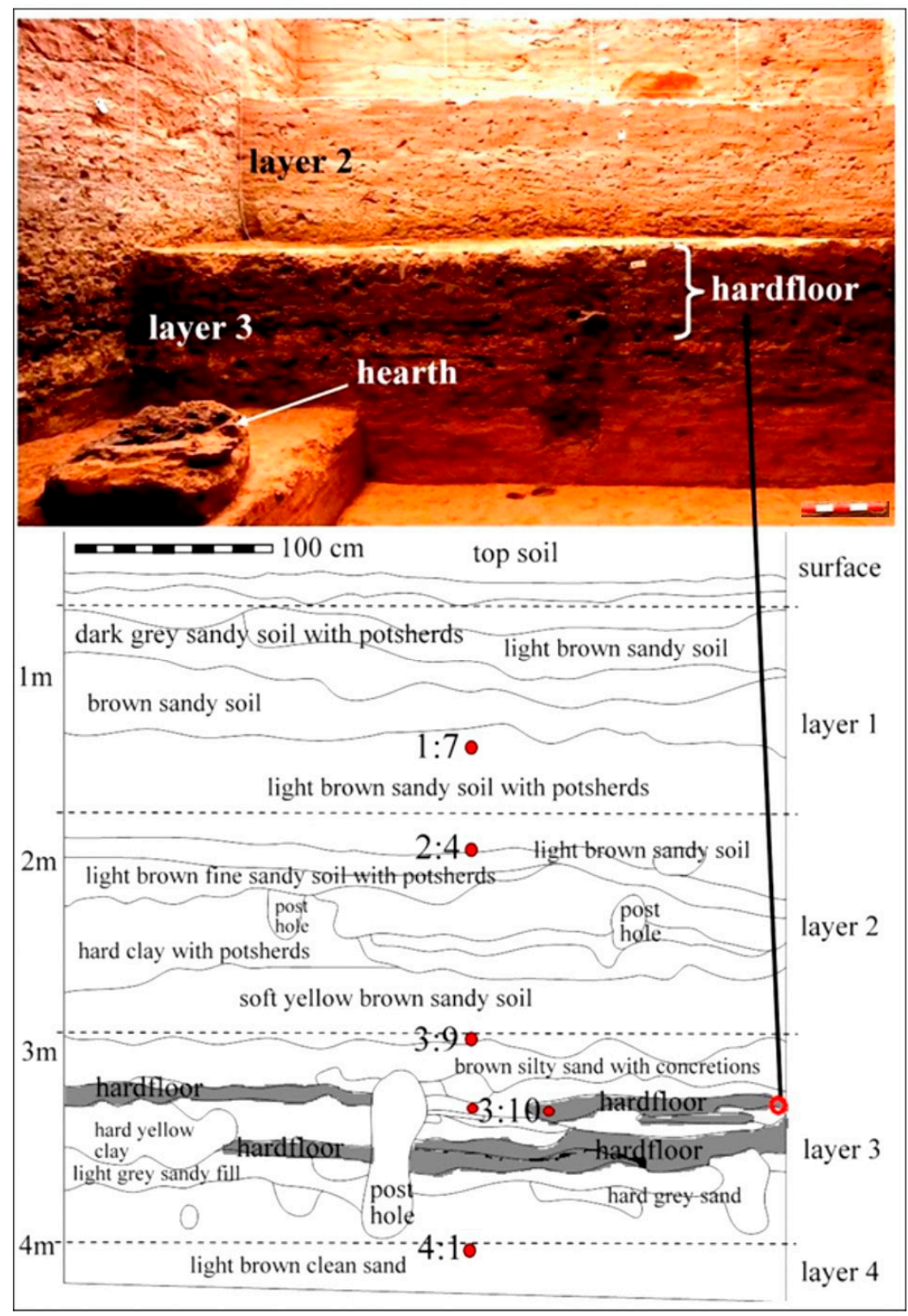

Figure 5. Example of stratigraphic context in HI100 excavation (the red dots indicate the sampling context; layer number: spit number) (Photograph: Nigel Chang; Line diagram: Nelum Kanthilatha).

\subsection{Statistical Analysis}

The mean grain size, standard deviation, skewness and kurtosis of the samples were calculated following Folk and Ward's method [19]. The grain size distribution and statistical package for the analysis of laser granulometer sediments (Gradistat, version 8.0) developed by Simon Blott and Pye [20] was used to calculate the mean grain size, sorting, skewness and kurtosis of the samples. Sand, silt, and clay diagrams were plotted according to the particle size distribution classification presented by Blott and Pye [17].

\subsection{Geochronology}

The 76 radiocarbon samples were obtained by Higham in 2011 [12] and provide a definitive chronological framework for the entire sequence from the Neolithic to the end of the Iron Age, and have allowed an analysis of the flow of life at Ban Non Wat based mainly on the patterning of human burials, the superposition of burials and similarities in mortuary behaviors. The cultural sequence of the site began with a probable hunter-gatherer group and ended in the late Iron Age [16,18,21,22]. 
Neolithic occupation layers have found from the excavation pits of G104 and N96 (and also N100, TU199 and V200; not mentioned in this study) approximately mark the area of initial occupants (Figure 6). When the population increased, the occupation area most likely spread radially towards the edge. As an example, the excavation pit of P300—which is at the edge of the mound-evidenced a human population since the Bronze Age. The buried channel features found through the excavation pits of U200 (TU199 and K500, not mentioned in this study) may evidence a new water source; however, it is hard to say that this channel is a natural phenomenon or a constructed one. A further two moat features are clearly visible around the Ban Non Wat site (Figure 2), and may indicate that another water body had been constructed after the infilling of the previous channels.

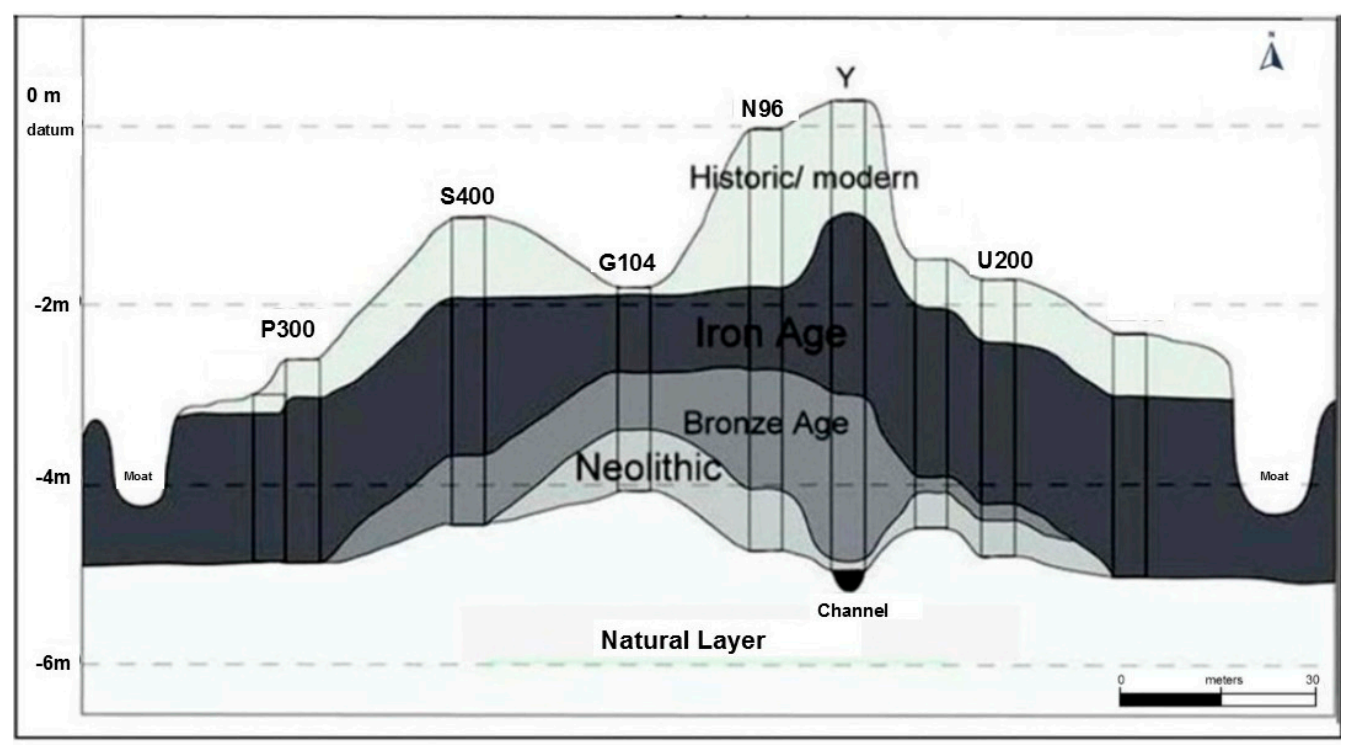

Figure 6. Basic stratigraphic profile of Ban Non Wat from west to east indicating the distribution of the settlements in different periods (image from Nigel Chang).

\section{Results}

\subsection{General Sedimentological Results of the Sediments}

The grain size parameters of the textural group—sorting, skewness and kurtosis—were analyzed according to the Folk and Ward method [19], and the description of each parameter is tabulated in six excavation pits representing different cultural layers of occupation. The mean grain size of the sediments ranged between 13.38 and $190.77 \mu \mathrm{m}$, and standard deviations ranged between 2.94 and 8.35 . Skewness values ranged between -0.41 and 0.34 and kurtosis values ranged between 0.70 and 1.41. The distribution of particle size in each excavation pit was illustrated using a sand-silt-clay triangle (SSC trigon) (Figure 7). The excavation pit of G104 identified seven layers, and layer six represents the hard floor sediments. The excavation pit of N96 spreads among six occupation layers: layer four has a main well-preserved hard floor and P300 spread among seven layers, and layer five represents the hard floor sediments. The S400 pit has six layers; layer three represents the hard floor sediments. The neighboring site of the HI100 excavation pit represents only four layers of occupation, and layer three has the most conspicuous clay floor sediments. The excavation pit of U200 represents the buried channel sediments (Figure 3). 


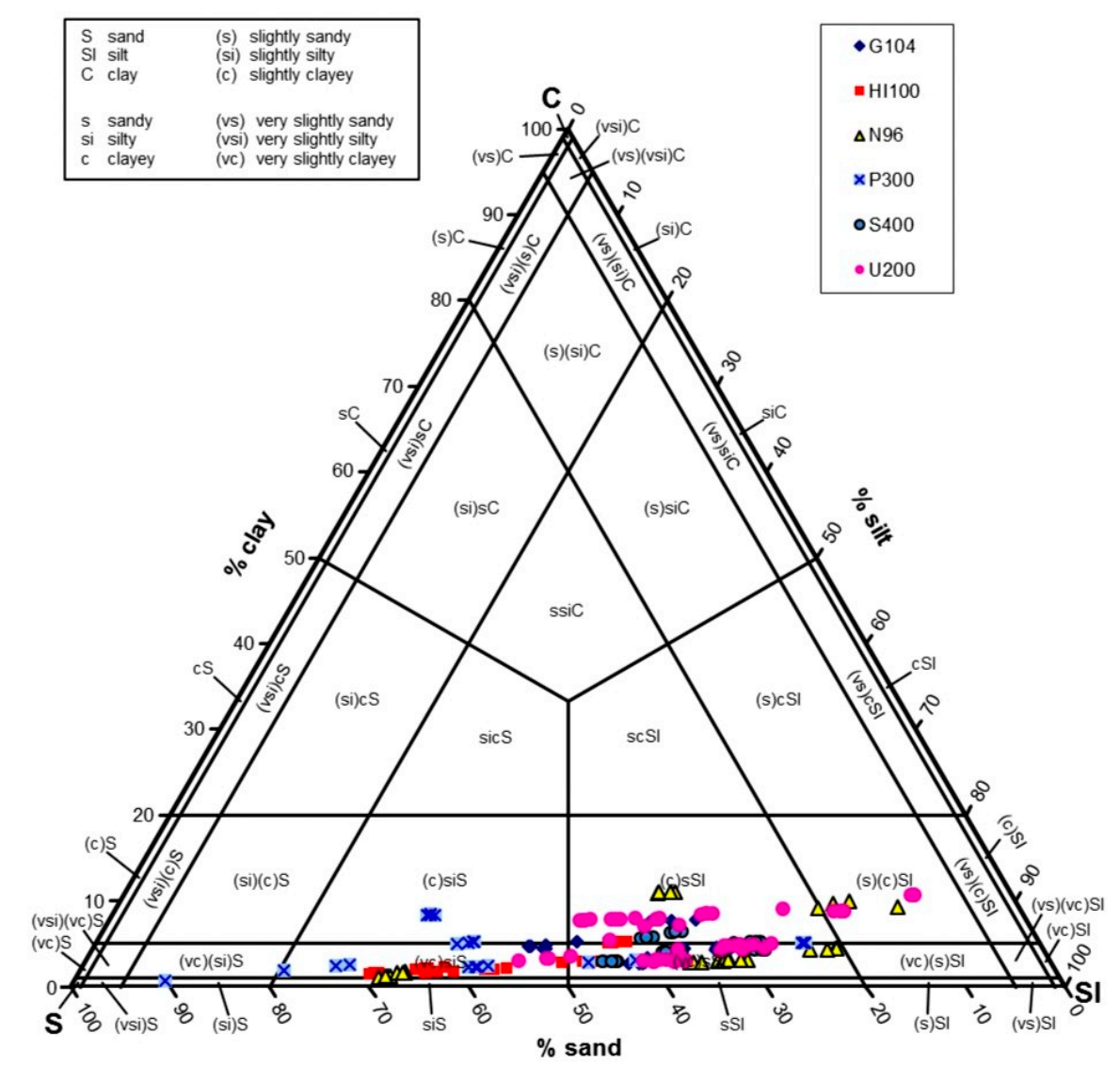

Figure 7. Particle size distribution diagram of the samples. Sediment samples can be clustered into four main groups according to the textural groups. Most of them have silty-sand and sandy-silt texture.

\subsection{Sedimentary Characteristics of Samples}

Sediments in the Mun valley floodplain area have been derived mainly from the floodplain sediments. Seasonal flooding is characteristic to the study site. Therefore, the initial origins of the sediments are largely similar, although there are some distinctions. Generally, the sediments are sandy-silt, very poorly sorted, fine skewed and mesokurtic. Differences in skewness and kurtosis, however, indicate distinctions between clusters of sediments. Negative skewness results from HI100 and U200 channel fill sediments, all the layers of G104 except layer six, and some layers of P300, S400, N96, and U200 mean that their coarser grains are less well sorted than finer grains. This produces a long, more gently sloped coarse tail. Two samples from N96 and U200 have a positive skewness and their finer grains are more poorly sorted than coarser grains, producing a long, more gently sloped fine tail. Other studies samples have a symmetrical skewness. All studied samples of G104, U200 (channel filling and above channel) sediments and some layers of P300, S400, N96, HI100 and U200 (BC and WC) have a normal kurtosis distribution. Layer 6 of N96, S400 (layer 3 and 6), and U200 (BC) have a platykurtic and others have leptokurtic distribution. Kurtosis is relatively more influenced by the dominant size mode in the particle size distribution [23].

Overall, the particle size distribution of the sediment samples clustered into four regions in the SSC trigon (Figure 7), based on the sand and silty content of the sediments. Four main sedimentary groups were identified in the study area, namely sand (SD1); silty-sand (SD2); sandy-silt (SD3); and silt (SD4). These sedimentological groups (SD1-SD4) provide the basis for outlining the basic sedimentary characters of the sites (Table 2). In summary, the prominent sediment type across the site of Ban Non Wat belongs to the sedimentological group SD3, while sedimentological groups SD2 and SD3 are the widely distributed across the study sites. No clear difference was identified between the sites of Ban Non Wat and Nong Hua Raet (Figure 7). 
Table 2. Main Sedimentary groups identified in the study area.

\begin{tabular}{ccc}
\hline Sedimentary Group & Prominent Texture & Main Archaeological Feature \\
\hline SD1 & sand & General spits \\
SD2 & silty-sand & General spits \\
SD3 & sandy-silt & Hard floors, Channel sediments \\
SD4 & silt & Channel sediments \\
\hline
\end{tabular}

\section{Discussion}

What does the sedimentology mean for the archaeology of the site? Sedimentologically, the archaeological features of general spits, hard floors and in-situ channel sediments appeared to be closely related. The broad similarity of sedimentological character provides the more interesting discussion regarding the origins of archaeological sedimentary features (Table 2), and opens up the possibility for a discussion of the relationship between archaeological features.

General spit sediments collected from the sites of G104, N96, P300, S400 and HI100 represented, mainly, the sedimentological groups of SD1 and SD2. Hard floor samples collected from the same sites exclusively represented group SD3. Channel sediments collected from U200 mainly represented the groups of SD3 and SD4. Although the site of HI100 is at a different location, its sedimentological characters are similar to those at G104, suggesting a similar origin for the sediments and also suggesting a reasonably uniform nature of the sediments throughout the sites, and, importantly, a common geological provenance. Such findings align well with previous studies and recognized that the sources of the archaeological sediments on the archaeological sites of this region in different localities and contexts within this study area, were influenced by the surrounding floodplain [11-15]. While there is some differentiation between sample types, the overall impression is of a close similarity between channel sediments and the various archaeological sediments (Figure 7).

It is likely that surrounding mound sediments were the source of sediments resulting in the infilling of the channel during seasonal flooding or by runoff influenced by human activity. The sedimentary evidence indicates that these channels in-filled quickly during the late Iron Age [22]. In contrast, earlier channels were filled up with clay-best explained as the natural sedimentation of season floodplain flooding, and later channels were filled by suspended floodplain sediments [14].

Formation processes for the hard floor surfaces is remain debated in archaeology. Given the nature of the sediments filling and in the area of the channel, it seems likely that the hard floors were constructed or plastered using channel sediments. Diatom analysis has previously resulted in a similar conclusion [1]. A geochemical analysis of the same sediments also clearly clustered (PCA analysis) the hard floor sediments with the presence of phosphorus, calcium, potassium and ferrous in higher concentrations than to the general spit sediments [16]. Fine laminar layering of the clay floors has been recorded at these and other sites in the region [22], and it has been suggested that the construction process of these features was the same throughout the period of prehistoric occupation. The floors were plastered using thin coats of white clays [23-26].

The buried channel features have been studied at the macro (landscape) scale, and recent excavations indicate that micro- and meso-scale features appear to represent localized water management and hydro engineering intimately associated with the on-site development of prehistoric settlements. While it is clear that water channels play an integral role in the internal organization of settlements, that role is unknown, other than to imply that localized, day-to-day social behavior was closely associated with water management on site. While some of these features may have helped provide a water supply within the site, others may have been associated with metal working or other industrial uses, drainage or sewage. Elsewhere in this study area, there are micro-scale channels associated with cultivation, the modification and use of natural river channels, and the presence and use of river/floodplain shoreline structures. These features have a great potential to provide rich evidence of connection between the daily social life of the occupants and the channel features, throughout a long period of prehistory in this region $[1,27]$. These observations reinforce the findings 
of the sedimentological studies presented here, especially in drawing a close association between the natural sediments of the floodplain and the anthropogenic sediments of the archaeological layers. Nevertheless, further research is needed to examine the finer details of this relationship, such as that between the channel features in relation to hard floor construction.

These observations fit with many years of detailed archaeological excavation, which has revealed complex site sedimentary histories [11-16]. Such work has provided evidence for environmental change and the human-environment relationships associated with these that allow us to start developing deeper and more nuanced understandings of socio-environmental processes [14,15]. Excavations at new localities, both at Ban Non Wat and elsewhere in the study region, have focused more strongly on the sedimentary record as an archaeological artefact, and are thus now able to raise new questions regarding the construction history of the sites, the history of human behavior at these sites, socio-spatial relationships between paleo-social activity and natural resources, and fine-scale landscape associations between sites. When all these considerations are taken into account, the sedimentological analysis of particle size distribution can be a powerful tool in acquiring information on archaeological sites.

\section{Conclusions}

The grain size distribution analysis presented here provides details of sediment layers and their sedimentological characters from several prehistoric site excavations in northeast Thailand. Particle size distribution was measured using a Malvern Mastersizer 2000 laser diffraction particle size analyzer with Hydro 2000 software, with a detection range of 0.01 to $10,000 \mu \mathrm{m}$. The overall results suggest a common origin of the sediments throughout the study area. Grain size analysis provides a way of differentiating the process of sediment transport resulting in channel infilling from both the archaeological site itself and from the surrounding floodplain. Similarities between the sediment characteristics of hard floors within the archaeological sequence, and the neighboring channel sediments suggest that the hard floors were created using channel clays. Such findings illustrate the potential of sedimentological analysis at archaeological sites in providing rich evidence of the connection between the site and its geology to the daily social life of the occupants, throughout a long period of prehistory in this region.

Supplementary Materials: The following are available online at http://www.mdpi.com/2571-550X/3/1/3/s1, Table S1: Description of sediment samples from Gradistat analysis based on the Fork and Ward method.

Author Contributions: Conceptualization, N.K. and W.B.; Methodology, N.K, W.B. and N.C.; Formal analysis, N.K and W.B.; Resources, W.B. and N.C.; Original Draft Preparation, N.K; Writing一review \& editing, W.B., Supervision, W.B. and N.C. All authors have read and agree to the published version of the manuscript.

Funding: This research was supported by a scholarship from Southern Cross University, Australia.

Acknowledgments: This research was completed at the Geoscience Laboratory, Southern Cross University. We thank to the Earthwatch Institute and many Earthwatch volunteers, volunteer students and to local villagers at Ban Non Wat and Nong Hua Raet in Thailand for their help for the excavations.

Conflicts of Interest: The authors declare no conflict of interest.

\section{References}

1. Kanthilatha, N.; Boyd, W.; Parr, J.; Chang, N. Implications of phytolith and diatom assemblages in the cultural layers of prehistoric archaeological sites of Ban Non Wat and Nong Hua Raet in Northeast Thailand. Environ. Archaeol. 2017, 22, 15-27. [CrossRef]

2. Kanthilatha, N. Sediments as Artefacts: Geoarchaeological Study of Prehistoric Sediments in Northeast Thailand. Ph.D. Thesis, Southern Cross University, East Lismore, NSW, Australia, 2016.

3. Kalicki, T. Grain size of the overbank deposits as carriers of paleogeographical information. Quat. Int. 2000, 72, 107-114. [CrossRef]

4. Layzell, A.; Mandel, R.D. Using soil survey data as a predictive tool for locating deeply buried archaeological deposits in stream valleys of the Midwest, United States. Geoarchaeology 2018, 34, 80-99. [CrossRef]

5. Graham, J. Collection and Analysis of Field Data: Techniques in Sedimentology; Blackwell Scientific Publications: Oxford, UK, 1988; pp. 5-62. 
6. Lewis, D.W.; McConchie, D. Practical Sedimentology; Chapman \& Hall: London, UK, 1994; pp. $124-155$.

7. McManus, J. Grain Size Determination and Interpretation. In Techniques in Sedimentology; Tucker, M., Ed.; Blackwell Scientific Publications: Oxford, UK, 1988; pp. 63-83.

8. Tanner, W.F. Application of Suite Statistics to Stratigraphy and Sea-Level Changes. Principles, Methods, and Application of Particle Size Analysis; Cambridge University Press: Cambridge, UK, 1991; pp. 283-292.

9. Miall, A.D. Principles of Sedimentary Basin Analysis; Springer: New York, NY, USA, 1990; p. 668.

10. Blott, S.J.; Pye, K. Particle size distribution analysis of sand-sized particles by laser diffraction: An experimental investigation of instrument sensitivity and the effects of particle shape. Sedimentology 2006, 53, 671-685. [CrossRef]

11. Boyd, W.E.; McGrath, R.J. The geoarchaeology of the prehistoric ditched sites of the upper Mae Nam Valley, NE Thailand, III: Late Holocene vegetation history. Palaeogeogr. Palaeoclimatol. Palaeoecol. 2001, 171, 307-328. [CrossRef]

12. Higham, C. The Iron Age of the Mun Valley, Thailand. Antiq. J. 2011, 91, 101-144. [CrossRef]

13. McGrath, R.J.; Boyd, W.E. The chronology of the Iron Age 'moats' of northeast Thailand. Antiquity 2001, 75, 349-360. [CrossRef]

14. Boyd, W.E.; Chang, N. Integrating social and environmental change in prehistory: A discussion of the role of landscape as a heuristic in defining prehistoric possibilities in NE Thailand. In Terra Australis: 21: Altered Ecologies-Fire, Climate and Human Influence on Terrestrial Landscapes; Haberle, S., Stevenson, J., Prebble, M., Eds.; ANU Press: Canberra, Australia, 2010; pp. 273-297.

15. Boyd, W.E. Social change in late Holocene mainland SE Asia: A response to gradual climate change or a critical climatic event? Quat. Int. 2008, 184, 11-23. [CrossRef]

16. Kanthilatha, N.; Boyd, W.; Chang, N. Multi-element characterization of archaeological floors at the prehistoric archaeological sites at Ban Non Wat and Nong Hua Raet in Northeast Thailand. Quat. Int. 2017, 432, 66-78. [CrossRef]

17. Blott, S.J.; Pye, K. Particle size scales and classification of sediment types based on particle size distributions: Review and recommended procedures. Sedimentology 2012, 59, 2071-2096. [CrossRef]

18. Higham, C.; Higham, T. A new chronological framework for prehistoric Southeast Asia, based on a Bayesian model from Ban Non Wat. Antiquity 2009, 83, 125-144. [CrossRef]

19. Folk, R.L.; Ward, W.C. Brazos River Bar: A study in the significance of grain size parameters. J. Sediment. Petrol. 1957, 27, 3-26. [CrossRef]

20. Blott, S.J.; Pye, K. GRADISTAT: A grain size distribution and statistics package for the analysis of unconsolidated sediments. Earth Surf. Process. Landf. 2001, 26, 1237-1248. [CrossRef]

21. Higham, C. The Bronze Age of Southeast Asia: New insight on social change from Ban Non Wat. Camb. Archaeol. J. 2011, 21, 365-389. [CrossRef]

22. McGrath, R.J.; Boyd, W.E.; Bush, R.T. The paleohydrological context of the Iron Age floodplain sites of the Mun River valley, Northeast Thailand. Geoarchaeol. Int. J. 2008, 23, 151-172. [CrossRef]

23. O'Reilly, D.J.W. The discovery of clay-lined floors at an Iron Age site in Thailand- preliminary observations from Non Muang Kao, Nakhon Ratchasima province. J. Siam Soc. 1997, 85, 133-149.

24. Dibble, H.L.; Chase, P.G.; McPherron, S.P.; Tuffreau, A. Testing the reality of a "Living Floor" with archaeological data. Am. Antiq. 1997, 62, 629-651. [CrossRef]

25. Karkanas, P.; de Moortel, A.V. Micromorphological analysis of sediments at the Bronze Age site of Mitrou, central Greece: Patterns of floor construction and maintenance. J. Archaeol. Sci. 2014, 43, 198-213. [CrossRef]

26. Toonen, W.H.J.; Kleinhans, M.G.; Cohen, K.M. Sedimentary architecture of abandoned channel fills. Earth Surf. Process. Landf. 2012, 37, 459-472. [CrossRef]

27. Kanthilatha, N.; Boyd, W.; Dowell, A.; Chang, N.; Wohlmuth, H.; Parr, J. Identification of preserved fatty acids in archaeological floor sediments from prehistoric sites at Ban Non Wat and Nong Hua Raet in northeast Thailand using gas chromatography. J. Archaeol. Sci. 2014, 46, 353-362. [CrossRef]

(C) 2020 by the authors. Licensee MDPI, Basel, Switzerland. This article is an open access article distributed under the terms and conditions of the Creative Commons Attribution (CC BY) license (http://creativecommons.org/licenses/by/4.0/). 